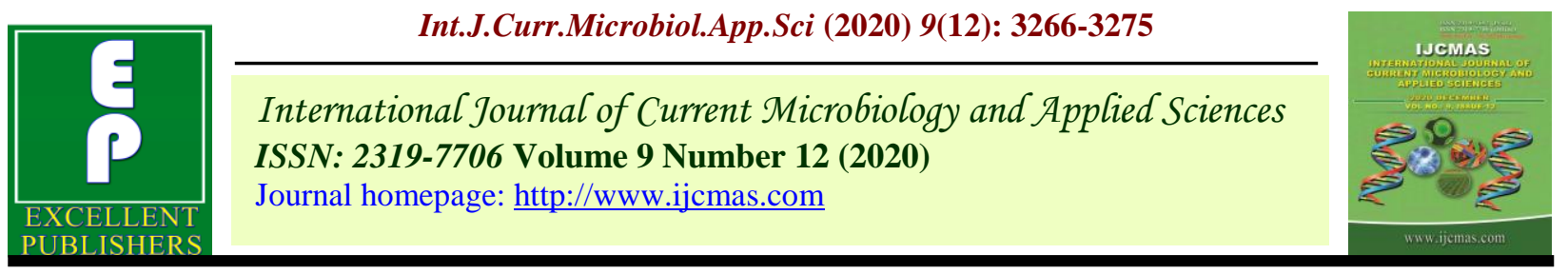

Original Research Article

https://doi.org/10.20546/ijcmas.2020.912.389

\title{
Wastewater Treatment of Artificial Sugar Mill Effluent through Medicinal Plant Sweet Flag and Water Hyssop on Floating Wetland Systems
}

\author{
Jhalesh Kumar ${ }^{*}$, Vinay K. Pandey ${ }^{2}$, Rajesh Singh ${ }^{3}$, \\ Sandeep Singh $^{3}$ and Sandeep K. Malyan ${ }^{4}$ \\ ${ }^{1}$ Department of Soil and Water Engineering, SV College of Agricultural Engineering and \\ Research Station, FAE, Raipur, Chhattisgarh, India \\ ${ }^{2}$ College of Agriculture and Research Station, Kurud, Chhattisgarh, India \\ ${ }^{3}$ Environmental Hydrology Division, National Institute of Hydrology, \\ Roorkee, Uttrakhand, India \\ ${ }^{4}$ Research Management and Outreach Division, National Institute of Hydrology, Roorkee, \\ Uttrakhand \\ *Corresponding author
}

\section{A B S T R A C T}

Keywords

Constructed

wetlands, Sweet

flag, Water hyssop,

Biological oxygen

demand, Dissolved

oxygen

Article Info

Accepted:

25 November 2020

Available Online:

10 December 2020
Jiggery cake has been introduced into aquatic ecosystem, which could lead to potential negative consequences for the BOD and DO of that aquatic ecosystem. An artificial floating wetland planted with Vachha (Acorus calamus) and Brahmi (Bacopa monnieri) was evaluated. Brahmi and vachha also known as water hyssop and Sweet flag respectively. $\mathrm{pH}, \mathrm{EC}$, BOD and DO were monitored continuously for every 15 day interval on 2 months. In this study we assured the contaminant removal potential of two plant species Vacha (Acorus calamus) and Brahmi (Bacopa monnieri) from wastewater in artificial floating wetland system. Sweet flag and water hyssop removal wastewater BOD from $63-75 \%$, and $67-81 \%$ respectively.

\section{Introduction}

Potable water is the most essential natural resources for life. Water is the only natural resource that exit in all three states (solid, liquid, and gas). This precious resource is consumed by human, plants, livestock, and many others directly. Consumption and discharge rate of water abruptly upsurge after industrialization, and modernization of agriculture. Discharging of untreated wastewater into environment leads to contaminations of fresh water resources (Kumar et al., 2019; Malyan et al., 2019). Wastewater discharged from households, industries, storm runoff, agricultural runoff, mining activity, etc., have high level of organic matter load, nitrogen, phosphorus, 
heavy metals, pesticides, antibiotics, etc. (Singh et al., 2018, 2012) and they should be removed before discharged in to any external water bodies. High organic and nutrient load, have negative impact of water bodies and they change the microbial and macro population. Pesticides and heavy metals are carcinogenic in nature and have adverse effect on human health (Kumar et al., 2019). Presently, many wastewater treatments methodologies such as coagulation (Kumar et al., 2018), phytoremediation (Kumar et al., 2017a), microbial fuel cells (Kumar et al., 2017b), reverse osmosis (Zhao et al., 2020), etc. were used for the treatment of wastewater globally. Chemical treatments systems are not cost effective and their application have limitations especially in developing countries. Therefore, biological treatments system such as constructed wetlands can be efficiently used for the onsite wastewater treatment in economical manner.

Constructed wetlands are decentralized, lowenergy, low-cost systems which are used for improving the water quality. They rely on natural wetland function which includes plants and microorganisms which uptake and breakdown the wastewater nutrients either aerobically or an aerobically. These systems are responsible for providing multiple benefits like improvement in water quality, water security \& reuse, $\mathrm{CO}_{2}$ reduction, provides habitat for many plants and animals. It also acts as a source for recreation, education, aesthetic/amenity value. Plants (free-floating, emergent or submergence vegetation) are the part of constructed ecosystem to remediate contaminants from municipal, industrial wastewater, metals, acid mine drainage. The performance of $\mathrm{CW}$ depends on many factors including its type and design, organic loading rate and hydraulic retention time (Vymazal, 2010). Selection of plant species for treatment of wastewater by $\mathrm{CWs}$ always remains a difficulty to scientists working in this area because metabolism of the macrophytes affects the treatment processes to different extents depending on the type of the $\mathrm{CW}$. The plants species used in CWs designed for wastewater treatment should therefore: (1) be tolerant of high organic and nutrient loadings, (2) have rich below-ground organs (i.e. roots and rhizomes) in order to provide substrate for attached bacteria and oxygenation (even very limited) of areas adjacent to roots and rhizomes and (3) have high above-ground biomass for winter insulation in cold and temperate regions and for nutrient removal via harvesting. The aim of this study is to the removal efficiency assessment of constructed wetlands for wastewater treatments.

\section{Materials and Methods}

\section{Description of study site and experimental design}

The present study was carried out in the experimental area of Environmental Hydrology Division, National Institute of Hydrology, Roorkee, India (Fig. 1) to assess wastewater treatment by Vacha (Acorus calamus) and Brahmi (Bacopa monnieri). Other common name of Vacha and Brahmi are sweet-flag and water hyssop respectively.

Healthy plant of both sweet-flag and water hyssop were collected from commercial botanical garden of Roorkee, Uttarakhand, India. Before using in experiment both the plants species are acclimatized in fresh water for the period of two weeks.

The experiment consist of three treatments namely 1- control (wastewater), 2-sweet-flag, and 3-water hyssop (Fig. 2). The experiment was carried out in complete randomized design (CRD) with triplicate of each treatment. The experiment was continuously run 60 days (from-1 March, 2019 to 30 April 2019). 


\section{Characterization of artificial sugar mill effluent}

When we mixed 250gram of bad quality jiggery on 1000liters fresh water then we notice water quality parameters were changed as compare to fresh water we found BOD level of this wastewater was ranges from 140 to $170 \mathrm{mg} / \mathrm{l}, \mathrm{pH}$ value was ranges from 6.14 to 7.24 , electrical conductivity was ranges from 500 to $710 \mu \mathrm{s} / \mathrm{cm}$ and dissolved oxygen was ranges from 0.6 to $1.38 \mathrm{mg} / \mathrm{l}$.

\section{Sampling, chemical analysis and analytical methods}

In this study synthetic wastewater is used and it was analyzed for physico-chemical parameter such $\mathrm{pH}, \mathrm{EC}(\mu \mathrm{S} / \mathrm{cm})$, dissolved oxygen $(\mathrm{mg} / \mathrm{L})$, and biological oxygen demand $(\mathrm{mg} / \mathrm{L})$. During the experiment, wastewater sample was taken out from each replication on $0,15,30,45$, and 60 days after experiment. Sampling and analysis were done as prescribed by APHA (2012).

$\mathrm{pH}$, and $\mathrm{EC}$ were measured on site using $\mathrm{pH}$ electrode (Model no-WTW Mutli 3320) and electrical conductivity meter (Model no-Hach HQ30d) respectively. DO, BOD, were measured in laboratory of the Division as per APHA (2012) standard protocol.

\section{Calculation of removal efficiency}

The removal efficiency of sweet flag and water hyssop for the reduction of contaminated was calculated using equation given below:

\section{Reduction $(\%)=($ Cin - Cout $) \mid$ Cin $) * 100$}

Where, Cin=pollutant concentration in inlet wastewater, and Cout=pollutant concentration in outlet wastewater.

\section{Statistical analysis}

Data collected from the experiment on various aspects were tabulated and analyzed statistically by using the technique of analysis of variance for randomized block design and analyzed by the method of analysis of variance as described by Gomez and Gomez (1984).

In order to compute the mean value of treatments, standard error and critical values were calculated as follow:

1. Standard error of mean SEm $\pm=\sqrt{ } \mathrm{Ve}$

2. Critical difference $(C D)=\operatorname{SEm}(d) \times t$ value at $5 \%$ error (df)

3. Coefficient of variation $(\mathrm{CV})=(\mathrm{Ve} / \mathrm{gm}) \mathrm{x}$ 100

Where,

$\mathrm{df}=$ degree of freedom,

ss $=$ sum of squares,

mss $=$ mean sum of squares,

$\mathrm{Ve}=$ error variance,

$\mathrm{r}=$ replication,

$\mathrm{gm}=$ general mean,

$\mathrm{t}=$ treatments

\section{Results and Discussion}

\section{Trends of $\mathrm{pH}$ and electrical conductivity} (EC)

Figure 3 a shows the variations of $\mathrm{pH}$ and EC in the control, sweet flag, and water hyssop treatments in this study. $\mathrm{pH}$ in control, sweet flag and water hyssop treatments were 6.42 , 6.53 , and 6.67 respectively, on 0 days after experiment (DAE) (Fig. 3a). In this study, wastewater $\mathrm{pH}$, in control, sweet flag, and water hyssop treatments rise slight on 15 DAE, and then reduced slight on 30 DAE (Fig. 3a). pH at the end of experiment (60, DAE) was $6.73,6.54$, and 6.67 in control, 
sweet flag, and water hyssop treatment respectively. This variation in $\mathrm{pH}$ may due to the change environmental factors such temperature, and rainfall. The change in temperature change the microbial population in constructed which may responsible for this trends of $\mathrm{pH}(\mathrm{V}$. Kumar et al., 2019).

The EC trends of in control, sweet flag, and water hyssop were represented in Fig. 3b. EC in control, sweet flag and water hyssop treatments ranged from 514 to $649(\mu \mathrm{s} / \mathrm{cm})$, $580-645(\mu \mathrm{s} / \mathrm{cm})$, and $542-637(\mu \mathrm{s} / \mathrm{cm})$ respectively, in study (Fig. 3b). In this study, wastewater EC was highest in the beginning of the study and it start drop with the progress in experiment. Irrespective to treatments, EC on $60 \mathrm{DAE}$ is lower than the $\mathrm{EC}$ on 0 days DAE (Fig. 3b).

\section{Removal efficiency of sweet flag and water hyssop in constructed wetland}

Variations in the biological oxygen demand (BOD), dissolved oxygen (DO) concentration were represented in Fig. 4. BOD and DO are generally inversely proportional in wastewater and they are affected by environmental parameters such as temperature, rainfall, etc. (Ansari et al.,
2015). BOD in the control treatment was significantly higher than sweet flag and water hyssop (Fig. 4a). Irrespective of treatments, the BOD in this reduced with time and it was higher on 0 DAE than the 60 DAE (Fig. 4a). BOD was significantly removed by sweet flag and water hyssop (Fig. 4a). Removal efficiency of BOD with control ranged from 19 to $31 \%$ (Table 1). The averaged performances (complete experiment) with control for the BOD removal were $23 \%$ (Table 1). Wastewater itself has microbial population which consumed organic matter as carbon source and therefore results in this reduction in even control treatment. The BOD removal efficiency with sweet flag, and water hyssop treatment was significantly higher than control and it ranged from 63 to $75 \%$, and 67 to $81 \%$ respectively (Table 1). The average BOD removal was $66 \%$ and $71 \%$ with sweet flag and water hyssop in this study (Table 1). Mean BOD removal in sweet flag, and water hyssop was $43 \%$ and $48 \%$ higher than control (Table 1). Sweet flag and water hyssop uptake several nutrient from wastewater including organic carbon for its growth and development(Noor et al., 2017) which had resulted in higher BOD reduction in this treatments.

Table.1 Removal efficiency (\%) of sweet flag and water hyssop in constructed wetlands

\begin{tabular}{|l|l|l|l|l|l|l|}
\hline \multirow{2}{*}{ Parameters } & \multicolumn{5}{|c|}{ Time (days) } \\
\cline { 2 - 7 } & 0 & 15 & 30 & 45 & 60 & Average \\
\hline Control & 18.75 & 20.00 & 25.00 & 21.43 & 31.25 & 23.29 \\
\hline BOD & 25.00 & 44.44 & 40.54 & 50.00 & 35.00 & 39.00 \\
\hline DO & & & & & \\
\hline Sweet flag & & & & & \\
\hline BOD & 62.50 & 67.0 & 63.0 & 64.0 & 75.00 & 66.19 \\
\hline DO & -75.00 & -56.00 & -89.00 & -92.00 & -120 & -86.28 \\
\hline Water hyssop & & & & & \\
\hline BOD & 68.75 & 66.67 & 68.75 & 71.43 & 81.25 & 71.37 \\
\hline DO & -62.50 & -44.44 & -71.17 & -108.33 & -140.00 & -85.29 \\
\hline -sign indicate higher than control & & & \\
\hline
\end{tabular}


Fig.1 Map showing study site (National Institute of Hydrology, Roorkee, India)

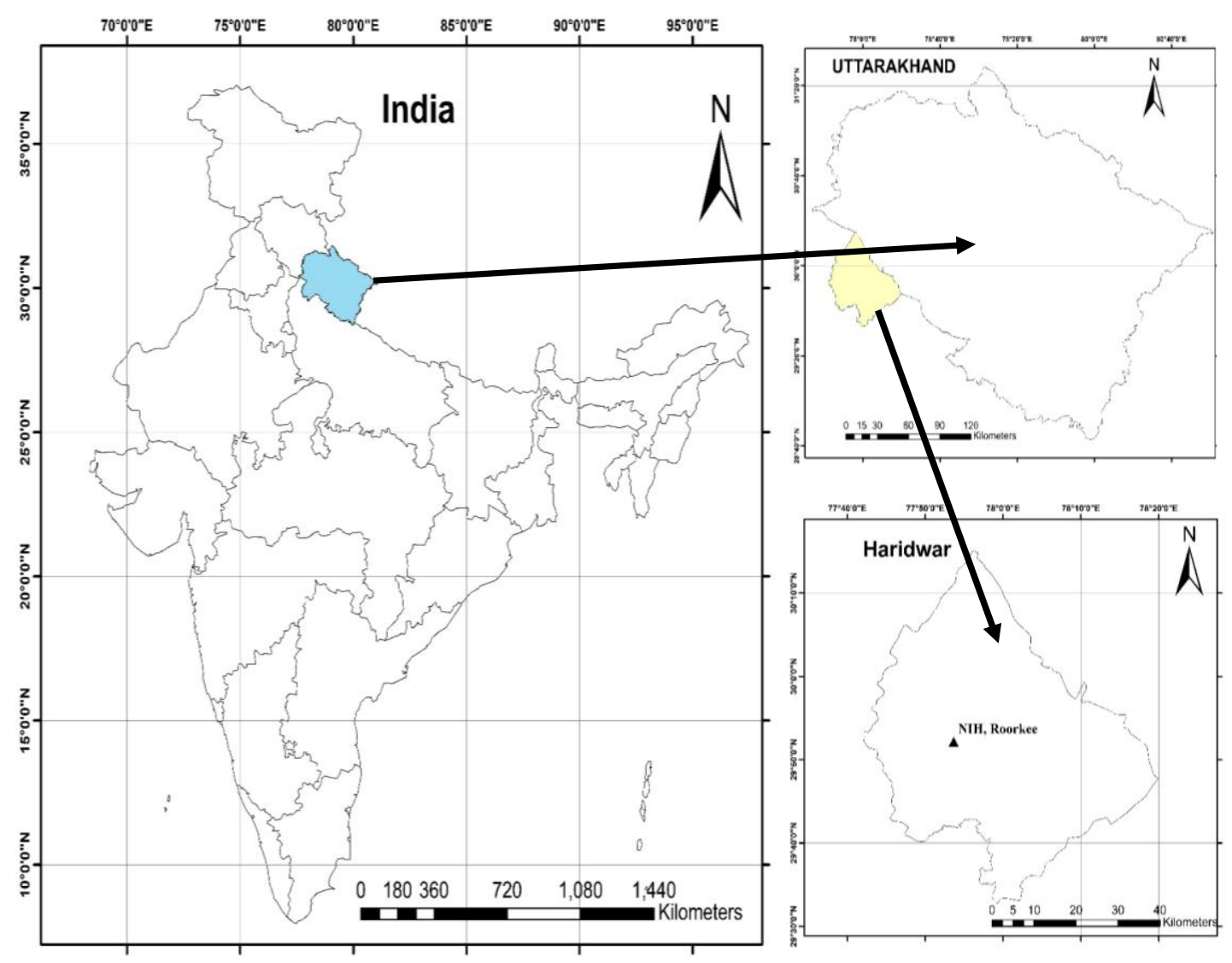

Fig.2 Experimental setup used in this study
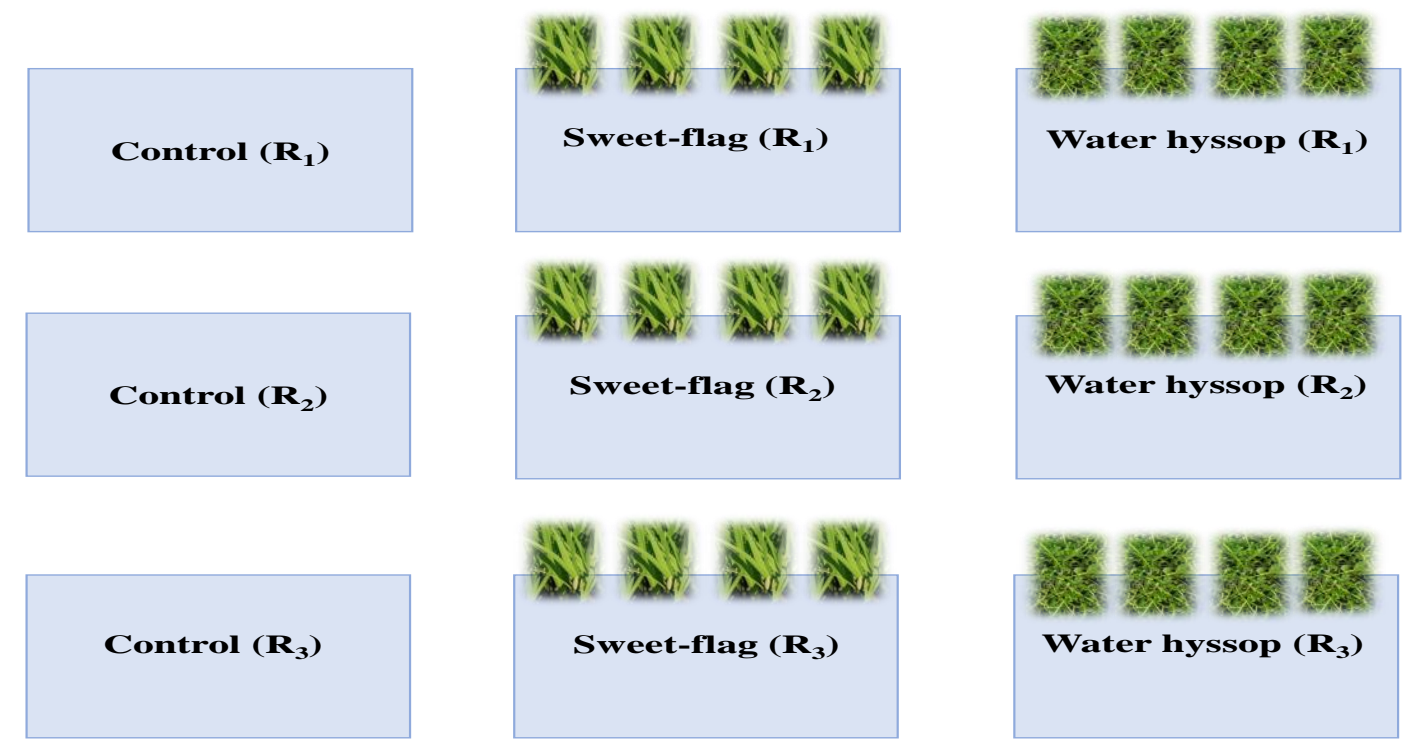
Fig.3 Trends of $\mathrm{pH}$ and $\mathrm{EC}$ in the phytoremediation experiment

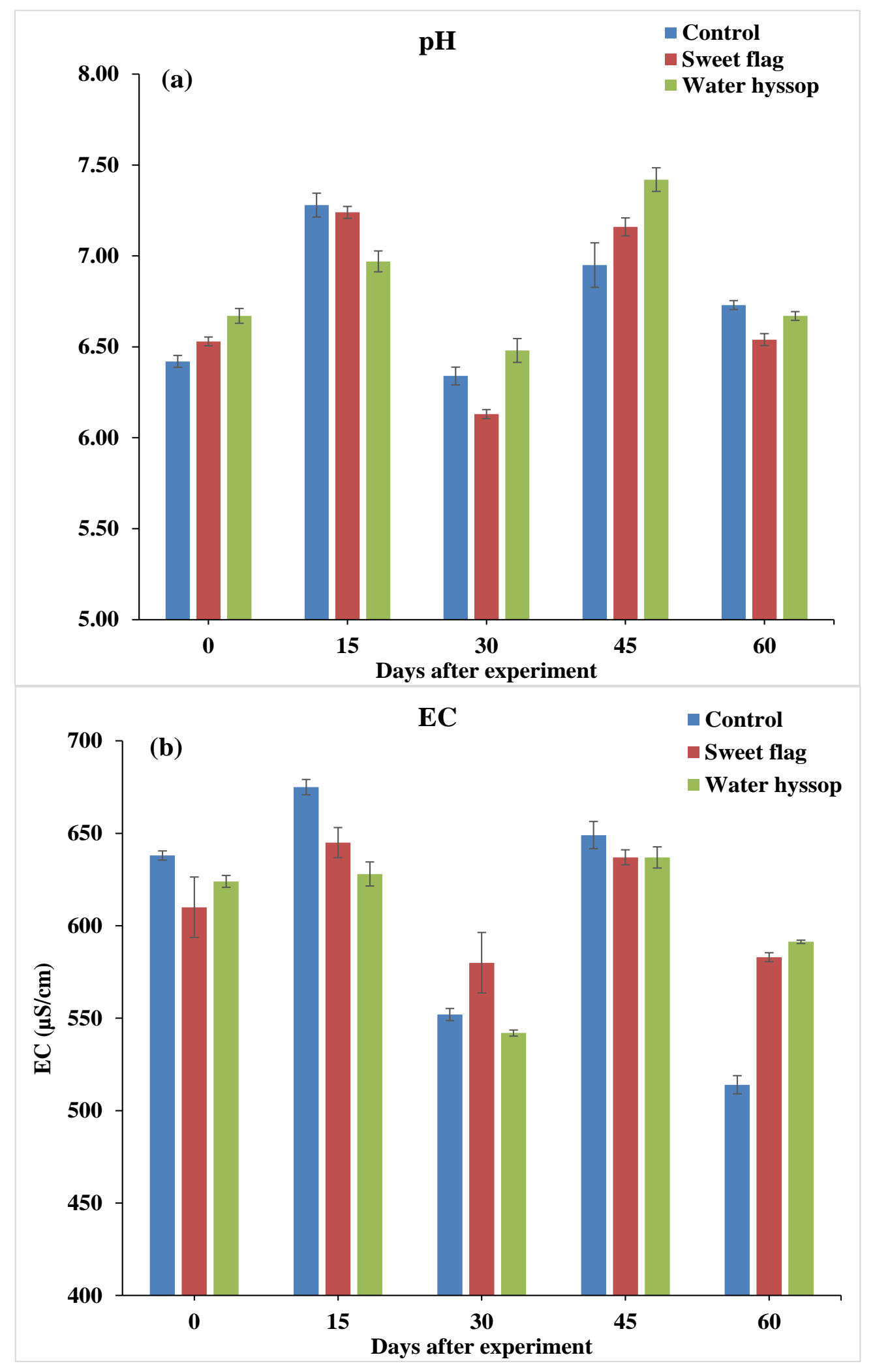


Fig.4 Variations of biological oxygen demand and dissolved oxygen

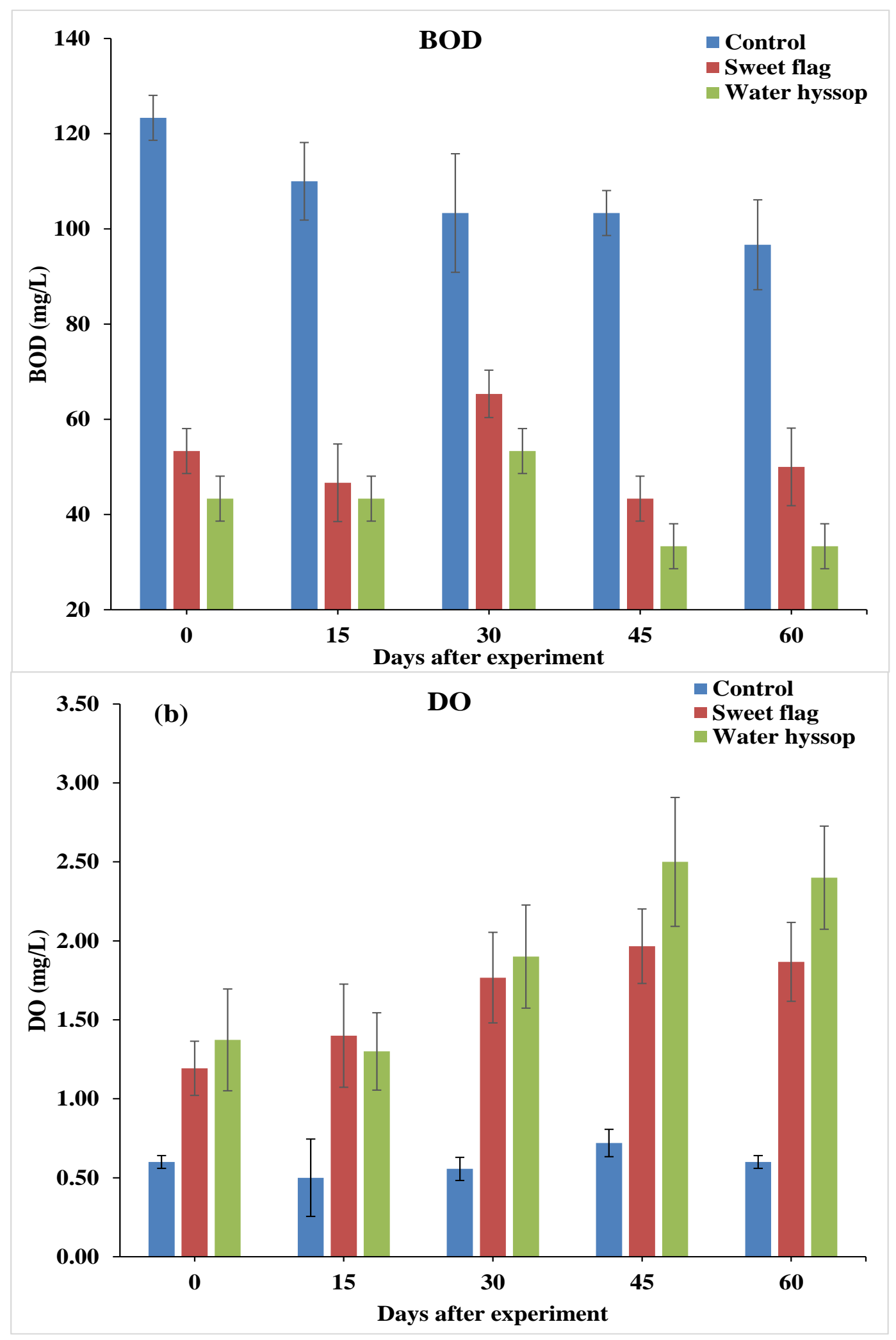


Fig.5
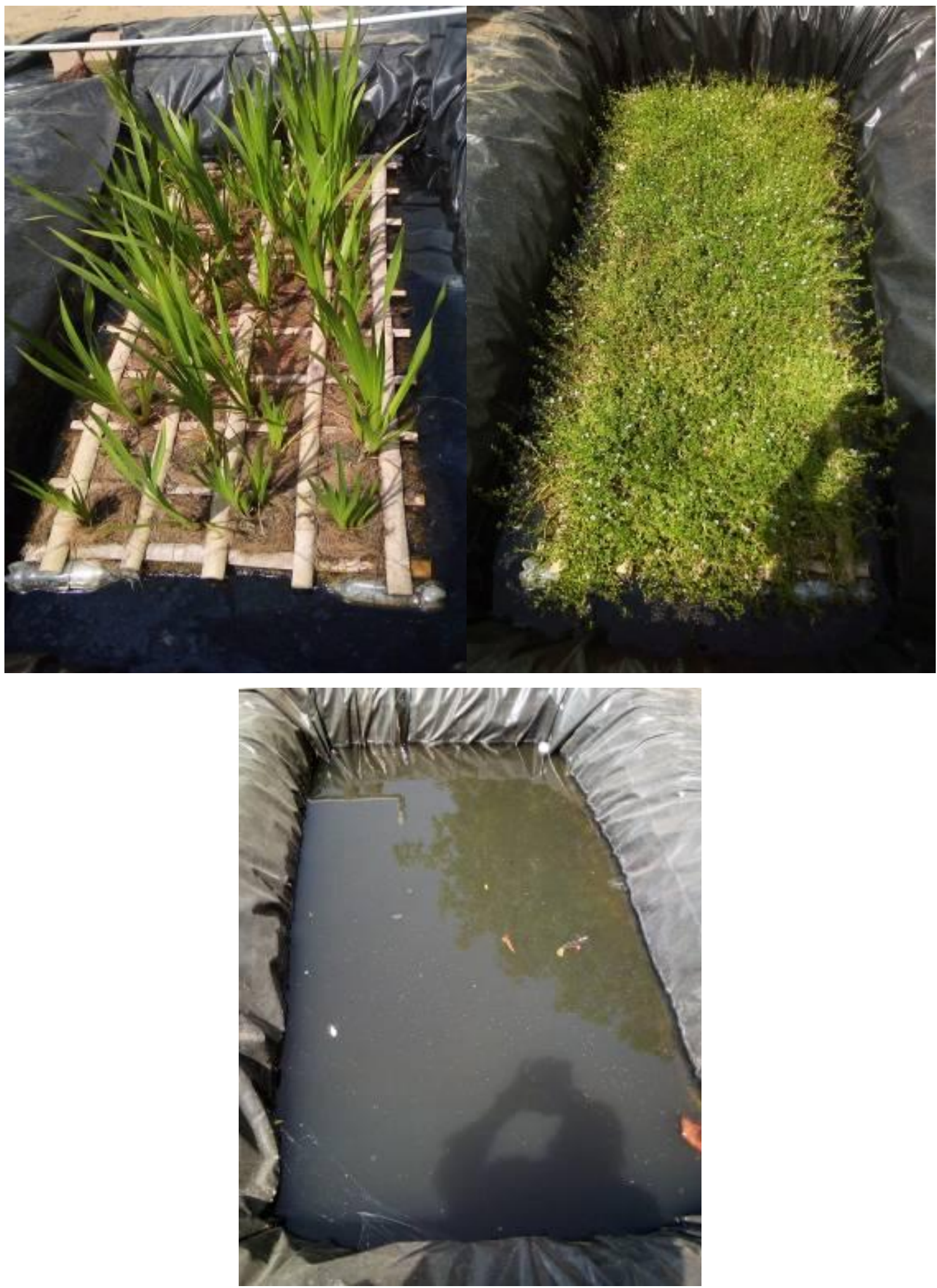
DO is one of the most crucial parameter which affect the microbial degradation in the bioremediation process. In this study, DO in control treatment was lowest (Fig. 4b). The concentration of DO increased with removal of organic pollution load. The concentration of DO at the end of experiment of higher then the DO concentration in the starting of experiment (Fig. 4b). The DO in this study increased with time (Table 1). The average DO in water hyssop increased by $85 \%$ (Table 1) which might be due to lower organic pollution load at this stage.

Hence concluded, this study of constructed wetland using water hissop and sweet flag required as an effective and sustainable approach to treat wastewater. The result indicated high removal efficiency of BOD from wastewater in which water hissop and sweet flag removed BOD by $67-81 \%$ and $63-$ $75 \%$ respectively from wastewater and meet the standard regulation for clean water quality. Therefore the treated water can be used for gardening, groundwater recharging and direct discharge on stream.

\section{References}

Ansari, A.A., Gill, S.S., Gill, R., Lanza, G.R., Newman, L., 2015. Phytoremediation: Management of environmental contaminants, volume 2. Phytoremediation Manag. Environ. Contam. Vol. 2 2, 1-366. https://doi.org/10.1007/978-3-31910969-5

Kumar, A., Bharti, Malyan, S.K., Kumar, S.S., Dutt, D., Kumar, V., 2019. An assessment of trace element contamination in groundwater aquifers of Saharanpur, Western Uttar Pradesh, India. Biocatal. Agric. Biotechnol. 20, 101213.

https://doi.org/10.1016/j.bcab.2019.101

213
Kumar, D., Gaurav, V.K., Sharma, C., 2018. Ecofriendly Remediation of Pulp and Paper Industry Wastewater by Electrocoagulation and Its Application in Agriculture. Am. J. Plant Sci. 09, 2462-2479. https://doi.org/10.4236/ajps.2018.91217 8

Kumar, S.S., Ghosh, P., Malyan, S.K., Sharma, J., Kumar, V., 2019. A comprehensive review on Enzymatic Degradation of the Organophosphate Pesticide Malathion in the Environment. J. Environ. Sci. Heal. Part C 37, In Press.

Kumar, S.S., Kadier, A., Malyan, S.K., Ahmad, A., Bishnoi, N.R., 2017a. Phytoremediation and rhizoremediation: Uptake, mobilization and sequestration of heavy metals by plants, PlantMicrobe Interactions in AgroEcological Perspectives. https://doi.org/10.1007/978-981-106593-4_15

Kumar, S.S., Malyan, S.K., Bishnoi, N.R., 2017b. Performance of buffered ferric chloride as terminal electron acceptor in dual chamber microbial fuel cell. J. Environ. Chem. Eng. 5, 1238-1243. https://doi.org/10.1016/j.jece.2017.02.0 10

Kumar, V., Singh, J., Kumar, P., 2019. Heavy metal uptake by water lettuce (Pistia stratiotes 1.) from paper mill effluent (pme): Experimental and prediction modeling studies. Environ. Sci. Pollut. Res. 26. https://doi.org/10.1007/s11356019-04766-2

Malyan, S.K., Singh, R., Rawat, M., Kumar, M., Pugazhendhi, A., Kumar, A., Kumar, V., Kumar, S.S., 2019. An overview of carcinogenic pollutants in groundwater of India. Biocatal. Agric. Biotechnol. 21, 101288. https://doi.org/10.1016/j.bcab.2019.101 288 
Noor, N.B., Daud, A., Amansyah, M., Mallongi, A., 2017. Affectivity dose of Acorus calamus (Sweet flag) to reduce the ammonia in hospital wastewater. J. Environ. Sci. Technol. 10, 139-146. https://doi.org/10.3923/jest.2017.139.14 6

Singh, K., Singh, R., Malyan, S.K., Rawat, M., Kumar, P., Kumar, S., Sharma, M.K., Pandey, G., 2018. Health Risk Assessment of Drinking Water in Bathinda District, Punjab, India. J. Indian Water Resour. Soc. 38, 34-41.

Singh, V.K., Bikundia, D.S., Sarswat, A., Mohan, D., 2012. Groundwater quality assessment in the village of Lutfullapur
Nawada, Loni, District Ghaziabad, Uttar Pradesh, India. Environ. Monit. Assess. 184, 4473-4488. https://doi.org/10.1007/s10661-0112279-0

Vymazal, J., 2010. Constructed wetlands for wastewater treatment. Water (Switzerland) 2, 530-549. https://doi.org/10.3390/w2030530

Zhao, D.L., Japip, S., Zhang, Y., Weber, M., Maletzko, C., Chung, T.S., 2020. Emerging thin-film nanocomposite (TFN) membranes for reverse osmosis: A review. Water Res. 173, 115557. https://doi.org/10.1016/j.watres.2020.11 5557.

\section{How to cite this article:}

Jhalesh Kumar, Vinay K. Pandey, Rajesh Singh, Sandeep Singh and Sandeep K. Malyan. 2020. Wastewater Treatment of Artificial Sugar Mill Effluent through Medicinal Plant Sweet Flag and Water Hyssop on Floating Wetland Systems. Int.J.Curr.Microbiol.App.Sci. 9(12): 32663275. doi: https://doi.org/10.20546/ijcmas.2020.912.389 